\title{
Survey of the Culicide community (Diptera: Culicidae) in the Caatinga Biome, Bom
}

\section{Jesus City, Piauí, Brazil}

\author{
Comunidade de Culicídeos (Diptera: Culicidae) no Bioma Caatinga, Bom Jesus, Piauí, Brasil \\ Comunidad Culicideos (Diptera: Culicidae) en el Bioma Caatinga, Bom Jesus, Piauí, Brasil
}

\begin{abstract}
Mosquitoes are insects of great medical importance, acting as vectors of arboviruses and other pathogens that could be transmitted to humans. With the climate change many species of mosquitoes have adapted to survive in these altered conditions. The goal of this study was to describe the community of Culicidae in three gradients of environment within the Caatinga biome in the Bom Jesus municipality, Brazil. The environmental gradients included native forest, rural and urban areas. Mosquitoes were collected and the following variables were analyzed: total and relative species abundance, total and relative species frequency, diversity, domain, the correlation among meteorological data, genus and the similarity between areas. The captures were made monthly for three consecutive days for a one-year period. Passive capture was performed using CDC traps placed a minimum distance of 50 meters apart in each sampling site. The mosquitoes collected were identified as: Aedeomyia spp., Aedes spp., Anopheles spp., Culex spp., Coquillettidia spp., Psorophora spp. and Uranotaenia spp. The genres Aedes, Anopheles, Culex, Coquillettidia and Psorophora were present year-round in at least one of the areas. The most abundant genres were the Anopheles and Culex, respectively. The native forest contained the highest diversity. However, the highest abundance of individuals was found in the rural areas, suggesting species adaptation to anthropized environments. Overall, the high abundance of the genus Anopheles and Culex is a public health concern as these genres are known to be involved in the transmission of malaria, human filariasis, and arboviruses.
\end{abstract}

Keywords: Arboviruses; Passive collection; Mosquitoes; Rural area.

\section{Resumo}

Os mosquitos são insetos de grande importância médica, atuando como vetores de arbovírus e outros patógenos que podem ser transmitidos ao homem. Com a mudança climática, muitas espécies de mosquitos se adaptaram para sobreviver nessas condições alteradas. O objetivo deste estudo foi descrever a comunidade de Culicidae em três gradientes de ambiente dentro do bioma Caatinga na cidade de Bom Jesus, Brasil. Os gradientes ambientais incluíram mata nativa, área rural e urbano. Os mosquitos foram coletados e analisados: abundância total e relativa de espécies, frequência total e relativa de espécies, diversidade, domínio, correlação entre dados meteorológicos, gênero e similaridade entre áreas. As capturas foram feitas mensalmente por três dias consecutivos pelo período de um ano. A captura passiva foi realizada usando armadilhas CDC colocadas a uma distância mínima de 50 metros em cada local de amostragem. Os mosquitos coletados foram identificados como: Aedeomyia spp., Aedes spp., Anopheles spp., Culex spp., Coquillettidia spp., Psorophora spp. e Uranotaenia spp. Os gêneros Aedes, Anopheles, Culex, Coquillettidia e Psorophora estiveram presentes o ano todo em pelo menos uma das áreas. Os gêneros mais abundantes foram Anopheles e Culex, respectivamente. A floresta nativa continha a maior diversidade. Entretanto, a 
maior abundância de indivíduos foi encontrada em áreas rurais, sugerindo a adaptação da espécie a ambientes antropizados. No geral, a alta abundância do gênero Anopheles e Culex é uma preocupação de saúde pública, pois esses gêneros são conhecidos por estarem envolvidos na transmissão da malária, filariose humana e arbovírus.

Palavras-chave: Arboviroses; Coleta passiva; Mosquitos; Área rural.

\begin{abstract}
Resumen
Los mosquitos son insectos de gran importancia médica, que actúan como vectores de arbovirus y otros patógenos que podrían transmitirse a los humanos. Con el cambio climático, muchas especies de mosquitos se han adaptado para sobrevivir en estas condiciones alteradas. El objetivo de este estudio fue describir la comunidad de Culicidae en tres gradientes de ambiente dentro del bioma Caatinga en la ciudad Bom Jesus, Brasil. Los gradientes ambientales incluyeron bosque nativo, dirección rural y dirección urbana. Se recolectaron mosquitos y se analizó lo siguiente: abundancia de especies total y relativa, frecuencia de especies total y relativa, diversidad, dominio, correlación entre datos meteorológicos, género y similitud entre áreas. Las capturas se realizaron mensualmente durante tres días consecutivos por un período de un año. La captura pasiva se realizó utilizando trampas CDC colocadas a una distancia mínima de 50 metros en cada sitio de muestreo. Los mosquitos recolectados fueron identificados como: Aedeomyia spp., Aedes spp., Anopheles spp., Culex spp., Coquillettidia spp., Psorophora spp. y Uranotaenia spp. Los géneros Aedes, Anopheles, Culex, Coquillettidia y Psorophora estuvieron presentes durante todo el año en al menos una de las áreas. Los géneros más abundantes fueron el Anopheles y Culex, respectivamente. El bosque nativo contenía la mayor diversidad. Sin embargo, la mayor abundancia de individuos se encontró en áreas rurales, lo que sugiere la adaptación de la especie a ambientes antropizados. En general, la gran abundancia de los géneros Anopheles y Culex es un problema de salud pública, ya que se sabe que estos géneros están involucrados en la transmisión de la malaria, la filariasis humana y arbovirus.
\end{abstract}

Palabras clave: Arbovirus; Colección pasiva; Mosquitos; Zona rural.

\title{
1. Introduction
}

The Culicidae family, found within the Dipteran order, is divided into two subfamilies: Anophelinae (13 genres) and Culicinae (110 genera) (Harbach, 2013). A total of 3,570 species are distributed from temperate and tropical regions of the world (Almeida, 2011), but the highest biodiversity of Culicidae occurs in the pristine areas of tropical ecosystems. Culicidae provide important ecosystem services, such as pollination, transferring of biomass, and involvement in the community food web (Fang, 2010). The current ongoing habitat fragmentation and deforestation has reduced their richness worldwide, including Brazilian biomes (Guedes, 2012). Additional anthropogenic activities, such as urbanization, climate change, and population growth, have influenced the adaptation and natural selection of some culicid species; making them more able to survive in degraded environments (Medeiros-Sousa et al., 2015).

Furthermore, using shelter and other resources found inside or nearby people's homes, these insects have been responsible for growing concerns in public health (Liang, Gao \& Goul, 2015). The majority of Culicidae are hematophagous (Almeida, 2011), and transmission of infectious agents, such as viruses, helminths, and protozoans have been documented (Donalisio et al., 2017; Lima-Camara, 2016). The females of the culicid genus preferentially feed on wild and domestic animals, which continues the transmission of pathogens in enzootic cycles (Donalisio et al., 2017). However, some species, as Aedes sp. and Culex sp., have become adapted to feeding on human blood and are now recognized as a vector of diverse arboviruses like Chikungunya, Dengue, Yellow fever, West Nile, and Zika virus.

Since 2015, at least nine pathogenic arboviruses have been found circulating in human populations in Brazil, including those responsible for the epidemics caused by infection with the Zika, Chikungunya, and Dengue viruses (Figueiredo, 2015). Brazil has been a hotspot for these viruses, however, the biodiversity of culicids in remote regions, such as the unique caatinga biome in northeast Brazil, are still underestimated.

To date, there are few studies about mosquitoes biodiversity in the Caatinga biome in the state of Piaui, northeast of Brazil. Piaui state is one of the poorest regions in Brazil and presents a mosaic of forest, local communities, and agriculture. 
The State has experienced much advancement in soy plantations and deforestation. This environmental challenges and poverty may influence the biodiversity of culicid species.

This study describes the first report on the diversity of the mosquitoes (Diptera: Culicidae) found in Bom Jesus city, Piaui, located in the caatinga biome.

\section{Methodology}

The study was carried out in the municipality of Bom Jesus $\left(09^{\circ} 04^{\prime} 28^{\prime \prime} \mathrm{S}\right.$ and $\left.44^{\circ} 21^{\prime} 31^{\prime \prime} \mathrm{W}\right)$, Piauí State, Brazil and is characterized by a warm semiarid tropical climate with an annual six months dry period. The city is comprised of Cerrado, Cerradão and Caatinga biomes and receives an average of $944.4 \mathrm{~mm}$ of rain each year. Bom Jesus has 22,632 inhabitants, with $77.8 \%(7,627)$ residing in urban households and 22.2\% (5,005) residing in rural households (Piauí 2011). Study sites were selected randomly inside of the Caatinga vegetation.

\section{Mosquito Sampling}

Mosquito samples were collected monthly from June 2017 to May 2018. Collections took place within 24 hours of the new moon and continued for three consecutive days. We chose the new moon period for collection because light traps are more efficient in that period (Provost, 1959). Within the Caatinga vegetation, sampling sites sampling were randomly selected and marked with the following GPS coordinates:S1-rural address (rural 1: $9^{\circ} 2^{\prime} 25.40$ "S and $44^{\circ} 18^{\prime} 28.33$ "W; rural 2: $9^{\circ} 22^{\prime} 30.20^{\prime \prime}$ $\mathrm{S}$ and $44^{\circ} 18^{\prime} 29.18$ "W); S2- native forest (native 1: $9^{\circ} 3^{\prime} 38.08$ "S and $44^{\circ} 18^{\prime} 43.01^{\prime \prime} \mathrm{W}$; native forest $2: 9^{\circ} 3^{\prime} 39.522^{\prime \prime S}$ and 44 $\left.{ }^{\circ} 18^{\prime} 41.27^{\prime \prime} \mathrm{W}\right)$ and S3- urban address 1: $9^{\circ} 4^{\prime} 27.58^{\prime \prime S}$ and $44^{\circ} 21^{\prime} 49.05^{\prime \prime} \mathrm{W}$; urban 2: $9^{\circ} 4^{\prime} 31.32$ "S and $\left.44^{\circ} 21^{\prime} 49.45^{\prime \prime} \mathrm{W}\right)$ ( Figure 1). The traps were placed at $1.5 \mathrm{~m}$ from the ground according to the methodology de Santos-Neto and Lozovei (2008) adapted.

Figure 1. Study sites: native forest, urban and rural areas in Bom Jesus-Piauí, Brazil, 2018.

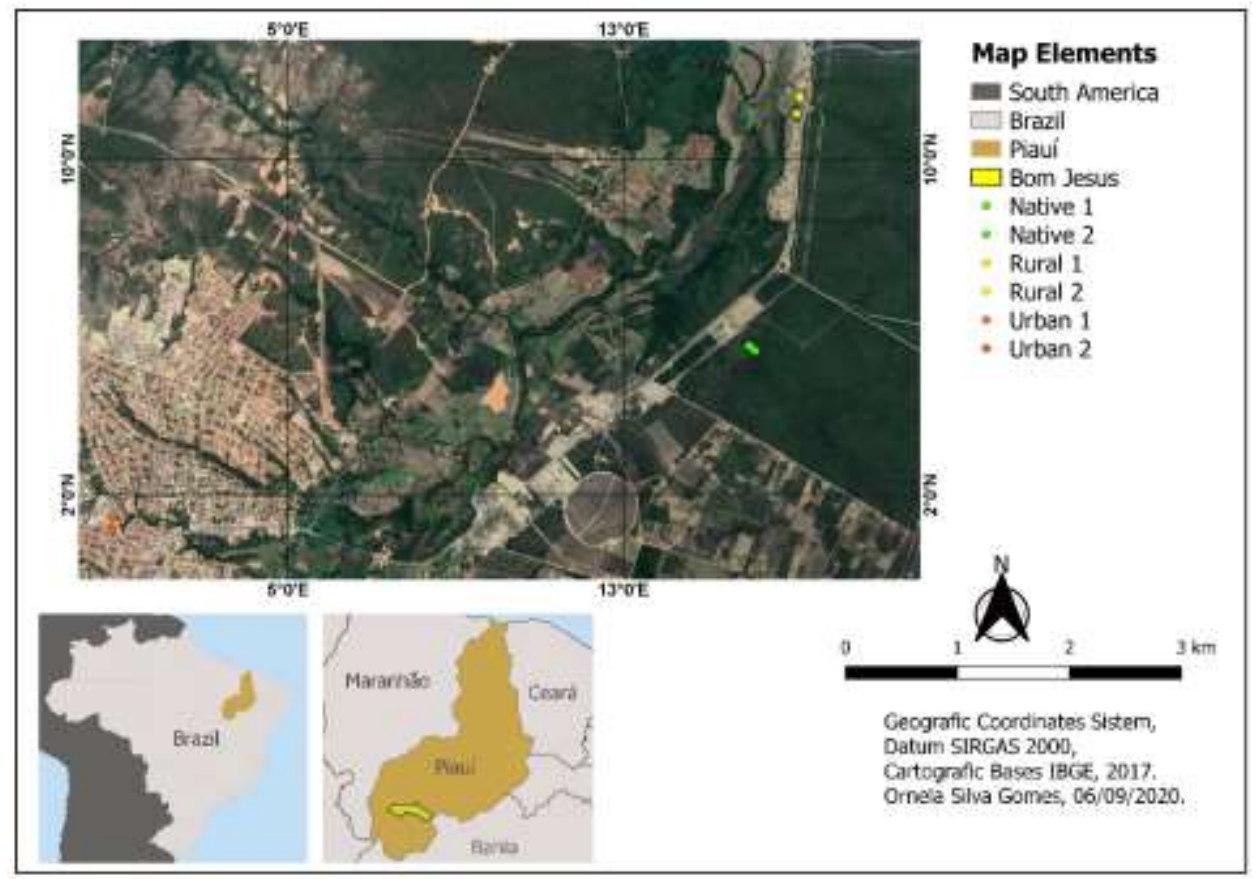

Source: Authors. 
Adult mosquitoes were collected using CDC light traps (CDC miniature Light trap Model 512, Bioquip Products, CA) installed a minimum of 200 meters away from the edge of the study site. Two traps were installed at each sampling site at least 50 meters apart, for a total of six traps.

The captured mosquitoes were confined in plastic containers with lids and labeled with their respective sampling sites and stored at $10^{\circ} \mathrm{C}$ in the zoology laboratory on the Federal University of Piauí-UFPI campus. The mosquitoes were induced to death by freezing because it helps to maintain the important characteristics for identification. Specimens were identified and separated using the keys provided by Consoli and Lourenço-de-Oliveira (1994).

\section{Weather data}

Meteorological data was obtained from the National Institute of Meteorology (INMET) database which extracts information from the automatic weather station (A326) located at 296m altitude (9º 08'32.51"S and -44 $\left.32^{\prime} 64.70^{\prime \prime} \mathrm{W}\right)$ in Bom Jesus municipality, Piaui. Meteorological data collected included minimum and maximum temperatures and minimum and maximum relative air humidity.

\section{Data analysis}

In each site, species diversity indices were obtained as well as richness, abundance and frequency (Silveira Neto et al., 1976). The Shannon's diversity was used for genus and Pielou and Jaccard indexes were used to compare the study areas. The environmental Relative Frequency was calculated using the formula $F R a=\frac{p i}{p} \times 100$ where 'pi' is the number of specie in the area, ' $\mathrm{P}$ ' is the total number of samples. The Genres Relative Frequency was calculated using the formula $F R a=\frac{n}{N} \times 100$ where ' $n$ ' is the total number of times that a genres occur in all areas, and ' $N$ ' is the total number of samples. The Relative Abundance was calculated using the formula $A b=\frac{n \times 100}{N}$, where ' $\mathrm{n}$ ' is the sum of genres individuals found in the area, and ' $\mathrm{N}$ ' is the sum of all individuals found in the area. To assess correlations between genres and climactic variables, the program SPSS (Statistical Package for the Social Sciences) version 9.0 was used.

\section{Results}

A total of 1,907 adult mosquitoes were collected within 7 genera: Aedeomyia $s p$. $(\mathrm{n}=110 ; 5.77 \%)$, Aedes sp. ( $\mathrm{n}=123$; 6.47\%), Anopheles sp. $(\mathrm{n}=673 ; 35.28 \%)$, Coquillettidia sp. $(\mathrm{n}=92 ; 4.82 \%)$, Culex sp. $(\mathrm{n}=592 ; 31.04 \%)$, Psorophora $(\mathrm{n}=302$; $15.84 \%)$, and Uranotaenia sp. $(\mathrm{n}=15 ; 0.78 \%)$ (Table 1). Overall, the subfamily Culicidae $(64.7 \%)$ was more dominant than the subfamily Anophelidae (35.3\%) where the Anopheles sp. (35.16\%), Culex sp. (30.93\%) and Psorophora sp. (15.77\%) represented almost $80 \%$ of all samples collected (Table 1). 
Table 1. Faunistic indices of genres of Culicidae (Diptera) in native, rural and urban environments, Bom Jesus-PI, 2018. RA = Relative Abundance; RF = Relative Frequence.

\begin{tabular}{|c|c|c|c|c|}
\hline \multirow{2}{*}{$\mathbf{H}$} & RA/Environment & RF/Environment & \multirow{2}{*}{ Total RA } & \multirow{2}{*}{$\begin{array}{c}\text { Total RF } \\
(\%)\end{array}$} \\
\hline & \multicolumn{2}{|c|}{$\begin{array}{l}\text { Native Forest } \\
\end{array}$} & & \\
\hline Aedeomyia & 10,06 & 33,33 & 5,77 & 83,33 \\
\hline Aedes & 11,32 & 66,67 & 6,45 & 100,00 \\
\hline Anopheles & 25,16 & 50,00 & 35,29 & 100,00 \\
\hline Coquillettidia & 5,66 & 41,67 & 4,82 & 100,00 \\
\hline Culex & 40,88 & 75,00 & 31,04 & 100,00 \\
\hline Psorophora & 5,66 & 50,00 & 15,84 & 100,00 \\
\hline \multirow[t]{2}{*}{ Uranotaenia } & 1,26 & 16,67 & 0,79 & 33,33 \\
\hline & \multicolumn{2}{|c|}{ Rural Area } & & \\
\hline Aedeomyia & 7,83 & 75,00 & & \\
\hline Aedes & 7,93 & 100,00 & & \\
\hline Anopheles & 59,54 & 100,00 & & \\
\hline Coquillettidia & 7,43 & 100,00 & & \\
\hline Culex & 8,73 & 91,67 & & \\
\hline Psorophora & 7,43 & 83,33 & & \\
\hline \multirow[t]{2}{*}{ Uranotaenia } & 1,10 & 8,33 & & \\
\hline & \multicolumn{2}{|c|}{ Urban Area } & & \\
\hline Aedes & 1,35 & 33,33 & & \\
\hline Culex & 63,24 & 100,00 & & \\
\hline Psorophora & 35,41 & 100,00 & & \\
\hline
\end{tabular}

Even with similar species richness, the native forest and rural site showed variations on abundance and relative frequencies among the genera sampled. In the native forest, Culex showed the highest abundance (AR) and higher frequency (AF), followed by Aedes sp. (Table 1). Considering the address rural site, the Anopheles genus showed the highest abundance, followed by Aedes sp. Furthermore, the genera Aedes, Anopheles, and Coquillettidia were collected in all months in the rural site (Table 1). In the urban site, the Culex sp. were more abundant and collected in all months (Table 1). This site also showed the lowest distribution of individuals in the genus among other sites, as demonstrated by the Pielou index (Table 2).

The Shannon and Pielou indexes revealed the highest diversity and equability of genera was found in the native forest. In contrast, the lowest values of these indices were found in the rural urban environment (Table 2).

Table 1. Diversity and similarity indices of Culicidae (Diptera) genres in forest, rural and urban environments, Bom Jesus-PI, 2018.

\begin{tabular}{lll}
\hline Environment & Shannon (H') & Pielou \\
\hline Native Forest & 1,57 & 0.81 \\
Rural Area & 1,36 & 0.70 \\
Urban Area & 0,72 & 0.65 \\
\hline
\end{tabular}

Source: Authors. 
Research, Society and Development, v. 10, n. 1, e46110111814, 2021

(CC BY 4.0) | ISSN 2525-3409 | DOI: http://dx.doi.org/10.33448/rsd-v10i1.11814

The urban site presented with the lowest species richness, while the species richness was similar between native forest and rural area (Tables 1, 2 and 3; Figure 2) with 7 genera each. The higher abundance was observed in rural area (n=996; $52.23 \%)$, followed by urban area $(n=593 ; 31.09 \%)$ and native forest $(n=318 ; 16.68 \%)$ (Table 3$)$. Fewer individuals from the genus Aedes sp. and Culex sp. tended to be trapped in the native forest where temperatures were lower (Table 3) while the genus Aedeomyia appears to be less abundant in the rural site because of the air humidity. 
Research, Society and Development, v. 10, n. 1, e46110111814, 2021

(CC BY 4.0) | ISSN 2525-3409 | DOI: http://dx.doi.org/10.33448/rsd-v10i1.11814

Table 3. Correlation of abundance of Culicídae family (Diptera), genres and climatic factors in forest, rural and urban environments, Bom Jesus-PI, 2018. RH\% = Relative Humidity; $\mathrm{T}^{\circ} \mathrm{C}=$ Ambient temperature in Celsius degree * significant at $0.01 ; * *$ significant at 0.0 .

\begin{tabular}{|c|c|c|c|c|c|c|c|}
\hline & Aedeomyia & Aedes & Anopheles & Coquillettidia & Culex & Psorophora & Uranotaenia \\
\hline \multicolumn{8}{|c|}{ Native Forest } \\
\hline Aedeomyia & & 0,042 & $0,699 * *$ & $0,598 * *$ & $0,652 * *$ & $-0,013$ & $0,457 * *$ \\
\hline Aedes & & & 0,188 & $0,344^{*}$ & 0,326 & $0,531 * *$ & 0,166 \\
\hline Anopheles & & & & $0,896 * *$ & $0,733 * *$ & $-0,028$ & $0,800 * *$ \\
\hline Coquillettidia & & & & & $0,844 * *$ & 0,050 & $0,785^{* *}$ \\
\hline Culex & & & & & & 0,006 & $0,610^{* *}$ \\
\hline Psorophora & & & & & & & 0,000 \\
\hline RH\%(average) & 0,009 & $-0,012$ & 0,013 & 0,024 & 0,097 & $-0,220$ & 0,144 \\
\hline RH\%(máxima) & $-0,031$ & 0,249 & 0,011 & 0,058 & 0,179 & $-0,077$ & 0,031 \\
\hline RH\%(mínimum) & $-0,043$ & 0,169 & $-0,013$ & 0,008 & 0,126 & $-0,095$ & $-0,006$ \\
\hline $\mathrm{T}^{\circ} \mathrm{C}$ (average) & 0,011 & $-0,255$ & $-0,155$ & $-0,193$ & $-0,089$ & $-0,104$ & $-0,066$ \\
\hline $\mathrm{T}^{\circ} \mathrm{C}$ (mínimum) & $-0,138$ & $-0,448 * *$ & $-0,137$ & $-0,313$ & $-0,404^{*}$ & 0,083 & $-0,270$ \\
\hline \multirow[t]{2}{*}{$\mathrm{T}^{\circ} \mathrm{C}$ (máxima) } & 0,044 & $-0,047$ & 0,046 & 0,054 & 0,024 & 0,103 & 0,022 \\
\hline & & & & Rural Area & & & \\
\hline Aedeomyia & & $-0,150$ & 0,158 & $-0,171$ & $-0,041$ & $-0,102$ & $-0,119$ \\
\hline Aedes & & & $0,568 * *$ & $0,579 * *$ & $-0,010$ & 0,006 & $0,414 *$ \\
\hline Anopheles & & & & $0,545^{* *}$ & $-0,121$ & $-0,086$ & 0,024 \\
\hline Coquillettidia & & & & & 0,014 & 0,025 & $0,346^{*}$ \\
\hline Culex & & & & & & $-0,081$ & 0,154 \\
\hline Psorophora & & & & & & & $-0,150$ \\
\hline RH\%(average) & $-0,173$ & 0,242 & 0,239 & 0,050 & $-0,109$ & $-0,017$ & $-0,129$ \\
\hline RH\%(máxima) & $-0,502 * *$ & 0,248 & 0,013 & 0,118 & $-0,163$ & 0,025 & 0,246 \\
\hline RH\%(mínimum) & $-0,507 * *$ & 0,288 & 0,037 & 0,124 & $-0,115$ & 0,040 & 0,292 \\
\hline $\mathrm{T}^{\circ} \mathrm{C}$ (average) & 0,067 & 0,198 & $-0,147$ & 0,066 & $-0,113$ & 0,125 & 0,066 \\
\hline $\mathrm{T}^{\circ} \mathrm{C}$ (mínimum) & 0,182 & 0,022 & 0,080 & $-0,026$ & 0,151 & $-0,415^{*}$ & 0,044 \\
\hline \multirow[t]{2}{*}{$\mathrm{T}^{\circ} \mathrm{C}$ (máxima) } & 0,271 & $-0,079$ & 0,060 & 0,048 & 0,084 & $-0,272$ & $-0,101$ \\
\hline & & & & rban Area & & & \\
\hline
\end{tabular}


Research, Society and Development, v. 10, n. 1, e46110111814, 2021

(CC BY 4.0) | ISSN 2525-3409 | DOI: http://dx.doi.org/10.33448/rsd-v10i1.11814

\begin{tabular}{llllrrr} 
Aedes & & & & 0,013 & $-0,011$ \\
Culex & & & & & $0,558^{* *}$ \\
RH\%(average) & 0 & $0,0,093$ & 0 & 0 & $-0,021$ & $-0,055$ \\
RH\%(máxima) & 0 & 0,170 & 0 & 0 & $-0,002$ & $-0,085$ \\
RH\%(mínimum) & 0 & $-0,118$ & 0 & 0 & $-0,010$ & $-0,121$ \\
$\mathrm{~T}^{\circ} \mathrm{C}$ (average) & 0 & 0,078 & 0 & 0 & $-0,078$ & 0,161 \\
$\mathrm{~T}^{\circ} \mathrm{C}$ (mínimum) & 0 & $-0,370$ & 0 & 0 & $-0,085$ & 0,207 \\
$\mathrm{~T}^{\circ} \mathrm{C}$ (máxima) & 0 & & 0 & 0,021 & 0,073 \\
\hline
\end{tabular}

Source: Authors.

Figure 2. Venn diagram showing the number of genders shared between native forest, rural and urban address environments and Jaccard similarity index. Where $\mathrm{E}=$ exclusive genres, $\mathrm{C}=$ common genres among the environment; $\mathrm{N}=$ number of genres sampled in the environments; $\mathrm{SJ}=\mathrm{Jaccard}$ Similarity Index.

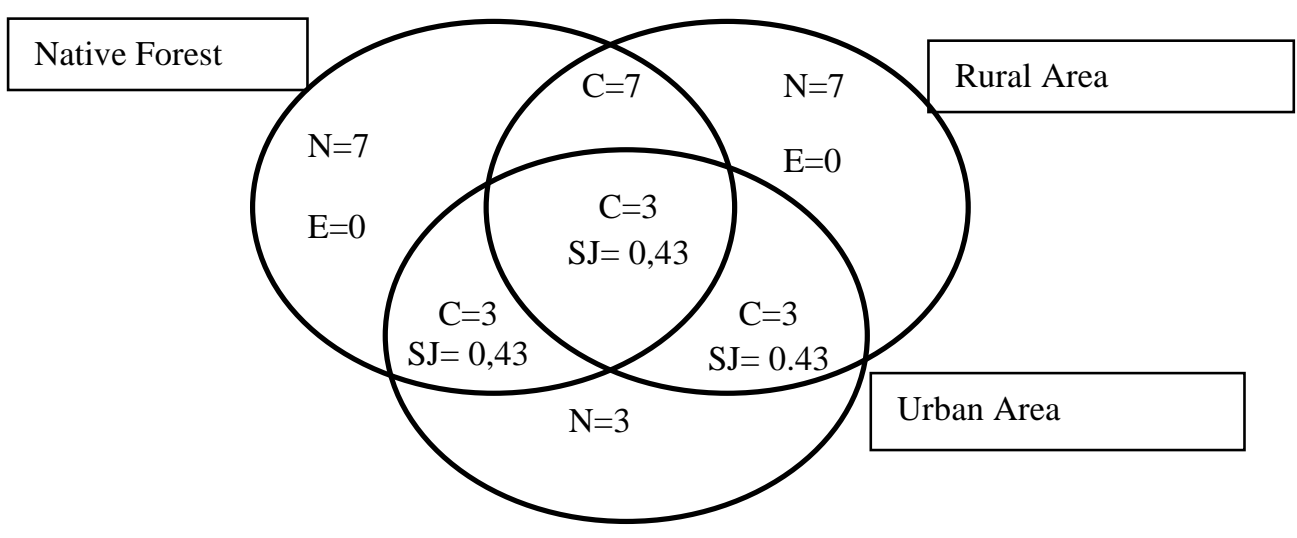

Source: Authors.

The highest temperatures and lowest humidity were found in the months from August to October (Table 4) and in the same period we observed the lowest abundance of mosquitoes in all three sampling sites. 
Research, Society and Development, v. 10, n. 1, e46110111814, 2021

(CC BY 4.0) | ISSN 2525-3409 | DOI: http://dx.doi.org/10.33448/rsd-v10i1.11814

Table 4. Minimum, maximum and average humidity and temperature from June 2017 to May 2018 in Bom Jesus city, Piauí.

\begin{tabular}{|c|c|c|c|c|c|c|c|c|c|c|c|c|}
\hline \multirow[b]{2}{*}{ Meteriologycal data } & \multicolumn{12}{|c|}{ Months } \\
\hline & JUN & JUL & AUG & SEP & OCT & NOV & DEZ & JAN & FEB & MAR & APR & MAY \\
\hline TEMP.max(9pm-9am) & 26.9 & 28.5 & 29.8 & 29.9 & 32.9 & 31.1 & 28.7 & 29.3 & 26.3 & 27.1 & 27.7 & 29 \\
\hline TEMP.max(9am-9pm) & 28.1 & 29.1 & 32.3 & 30.9 & 33.2 & 30.6 & 29.2 & 29.1 & 27.2 & 27.3 & 27.7 & 27.8 \\
\hline TEMP.min(9pm-9am) & 24.2 & 23.7 & 24.8 & 25.8 & 27.5 & 26.3 & 25.2 & 24.5 & 23.6 & 23.6 & 23.4 & 24 \\
\hline TEMP.min(9am-9pm) & 26.4 & 26.4 & 28.5 & 28.7 & 25.6 & 25.7 & 24 & 25 & 25 & 24.2 & 24.9 & 25.5 \\
\hline TEMP average & 26.15 & 26.4 & 28.55 & 28.35 & 29.4 & 28.4 & 26.6 & 26.9 & 25.4 & 25.45 & 25.55 & 26.5 \\
\hline UMID.max(9pm-9am) & 58 & 57 & 51 & 51 & 49 & 71 & 72 & 79 & 90 & 94 & 79 & 69 \\
\hline UMID.max(9am-9pm) & 41 & 44 & 32 & 28 & 62 & 82 & 86 & 79 & 90 & 90 & 80 & 68 \\
\hline UMID.min(9pm-9am) & 47 & 31 & 39 & 37 & 33 & 46 & 53 & 54 & 79 & 74 & 59 & 51 \\
\hline UMID.min(9am-9pm) & 35 & 25 & 22 & 25 & 20 & 40 & 44 & 42 & 62 & 69 & 63 & 41 \\
\hline UMID.average & 46.5 & 41 & 36.5 & 38 & 41 & 61 & 65 & 60.5 & 76 & 81.5 & 69.5 & 55 \\
\hline
\end{tabular}

Source: Authors.

However, among the three sampling sites, at least one individual from the genera Aedes, Anopheles, Coquillettidia, Culex and Psorophora were sampled each month, indicating the yearlong presence of the Culicidae family despite of seasonal variations (Table 5). 
Table 2. Number of individuals collected from the genres Aedeomyia, Aedes, Anopheles, Coquillettidea, Culex, Psorophora, Uranotaenia in native forest, rural and urban areas from June 2017 to May 2018 in Bom Jesus, Piauí.

\begin{tabular}{|c|c|c|c|c|c|c|c|c|c|c|c|c|c|}
\hline \multirow[b]{2}{*}{ Areas } & \multirow[b]{2}{*}{ Genus } & \multicolumn{12}{|c|}{ Months } \\
\hline & & JUN & JUL & AUG & SEP & OCT & NOV & DEC & JAN & FEB & MAR & APR & MAY \\
\hline \multirow{7}{*}{ Native Forest } & Aedeomyia & 0 & 12 & 1 & 0 & 0 & 0 & 0 & 0 & 1 & - & - & 18 \\
\hline & Aedes & 2 & 0 & 1 & 0 & 0 & 7 & 11 & 0 & 8 & - & - & 7 \\
\hline & Anopheles & 1 & 8 & 0 & 1 & 0 & 6 & 0 & 0 & 1 & - & - & 63 \\
\hline & Coquillettidea & 1 & 0 & 0 & 1 & 0 & 0 & 0 & 2 & 1 & - & - & 13 \\
\hline & Culex & 1 & 6 & 0 & 2 & 2 & 21 & 10 & 11 & 7 & - & - & 70 \\
\hline & Psorophora & 3 & 0 & 4 & 1 & 0 & 0 & 2 & 0 & 7 & - & - & 1 \\
\hline & Uranotaenia & 0 & 0 & 0 & 0 & 0 & 0 & 0 & 0 & 1 & - & - & 3 \\
\hline \multirow{7}{*}{ Rural address } & Aedeomyia & 10 & 8 & 34 & 6 & 5 & 0 & 3 & 4 & 0 & 0 & 1 & 7 \\
\hline & Aedes & 5 & 2 & 3 & 7 & 7 & 2 & 3 & 2 & 10 & 19 & 13 & 6 \\
\hline & Anopheles & 18 & 50 & 86 & 40 & 24 & 6 & 1 & 18 & 34 & 77 & 136 & 103 \\
\hline & Coquillettidea & 2 & 9 & 4 & 6 & 2 & 1 & 5 & 3 & 4 & 17 & 5 & 16 \\
\hline & Culex & 32 & 2 & 3 & 8 & 8 & 11 & 1 & 1 & 0 & 9 & 1 & 11 \\
\hline & Psorophora & 13 & 5 & 4 & 7 & 3 & 4 & 25 & 1 & 3 & 6 & 2 & 1 \\
\hline & Uranotaenia & 0 & 0 & 0 & 0 & 0 & 0 & 0 & 0 & 0 & 8 & 2 & 1 \\
\hline \multirow{7}{*}{ Urban address } & Aedeomyia & 0 & 0 & 0 & 0 & 0 & 0 & 0 & 0 & 0 & 0 & 0 & 0 \\
\hline & Aedes & 0 & 0 & 0 & 0 & 2 & 0 & 0 & 1 & 4 & 1 & 0 & 0 \\
\hline & Anopheles & 0 & 0 & 0 & 0 & 0 & 0 & 0 & 0 & 0 & 0 & 0 & 0 \\
\hline & Coquillettidea & 0 & 0 & 0 & 0 & 0 & 0 & 0 & 0 & 0 & 0 & 0 & 0 \\
\hline & Culex & 28 & 54 & 21 & 24 & 29 & 78 & 45 & 15 & 20 & 10 & 31 & 20 \\
\hline & Psorophora & 26 & 46 & 15 & 2 & 8 & 49 & 17 & 25 & 6 & 4 & 6 & 6 \\
\hline & Uranotaenia & 0 & 0 & 0 & 0 & 0 & 0 & 0 & 0 & 0 & 0 & 0 & 0 \\
\hline
\end{tabular}




\section{Discussion}

All genres of Culicidae collected in the present study are known to be trapped in anthropized areas or in sites with a high degree of degradation (Table 1). The anthropic interventions in the sampling sites of the native forest, such as wood removal and the presence of domestic and large animals, might explain the similarity of genres found between the native forest and the rural environment. As found in other studies, the lower diversity of culicids was already expected in urban environments, with genres Culex and Aedes dominating due to their adaption to anthropized environments and widely distribution in Brazil (Lopes, 2014). Between the years 2017-2018, the period of our research, a decrease in dengue cases was observed in the state of Piauí, despite that it is necessary to adopt preventive measures since this number quadrupled in the year 2019 ( Souza et al., 2020).

Culex's dominance over other genres in the urban area may be due to this genus having permanent breeding sites and the immature phase lasts for long periods regardless of low humidity (Natal, 2002) (Table 1). Furthermore, the Culex genus might have high adaptive activity, with species known in wild, rural and urban environments. In addition, the diversity of food preference in this genus varies from human to domestic animals and wild birds (Dibo et al., 2011). This genus represents a risk for public health, being the vector for the West Nile virus. The coexistence of migratory birds and Culicidae in forest areas and urban forest areas reveals risk for the introduction and transmission of West Nile Virus in human population (Dibo et al., 2011)

Although the Psorophora genus is more common in forests, studies have shown that this genus has adapted to extra domiciliar environment (Consoli \& Oliveira, 1994), as we found. The increase of abundance from November to May might be related by the higher incidence of rainfall, which supports the development of the larval phase of these insects (Table 3 ).

In the rural environment, it was observed that the genus Anopheles, known to be a vector of Malaria, was found in most months of the survey. This finding may be as a result of this genus having a known feeding presence for domestic animals (Consoli \& Oliveira, 1994) which are present in this area year round.

Species of the genus Aedeomyia are ornithophilic, vectors of plasmodia and Gamboa virus (Nascimento Pereira et al., 2017; Tantely et al., 2017). This genus was likely found in native forest and rural areas due to the presence of native birds and domestic poultry, respectively.

Despite of the wild behavior of the genus Coquillettidia, they are attracted by light sources in anthropic areas (Forattini et al., 1981; Catenacci et al., 2018 ) which explains the abundance in the rural sampling sites.

The genus Uranotaenia has preference for wetlands and feeding on cold-blooded animals such amphibians (Consoli $\&$ Oliveira, 1994). The presence of this genus at the rural site is likely due to the presence of a fishpond located nearby the CDC trap.

The correlation and similarity found between genders in the areas of native forest and rural area can be explained by the zoophilic habit of these culicids. In both rural and forested areas, vertebrates can be found allowing the feeding of the mosquitoes. In addition, the presence of water near the rural area facilitates the oviposition and reproduction of these insects.

\section{Conclusion}

The native forest and rural areas had higher diversity. The urban area had greater dominance and less similarity between the other areas. The diversity and high abundance of mosquitoes of the genus Culex sp, Aedes and Anopheles found in this study serves as a warning of the potential risk for the transmission of Malaria, Human Filariasis, and arboviruses such as West Nile, Dengue, Zika and Chikungunya in the Bom Jesus municipality. A long-term survey in other municipalities that have a higher occurrence of dengue cases in the state is suggested. And further surveys might consider the period of activity 
Research, Society and Development, v. 10, n. 1, e46110111814, 2021

(CC BY 4.0) | ISSN 2525-3409 | DOI: http://dx.doi.org/10.33448/rsd-v10i1.11814

(night/day) of the mosquitoes. The data was shared with the Municipality Health Service and preventive measures were made by placing nets in the windows of the houses and the use of insecticides. It is recommended to continue these surveys, with identification at the species level associated with the search for the presence of pathogens in these potential vectors, to support disease surveillance.

\section{Acknowledgments}

I would like to thanks to Evandro Chagas Institute (IEC), Zoonoses Control Center of Piauí, Esperança Farm, and Federal University of Piauí State (UFPI). To the National Institute of Meteorology for providing the meteorological database for this research. We are grateful to Dr. Whitney Collins for review the manuscript.

\section{References}

Almeida, A. P. G. de. (2011). Os mosquitos ( diptera , culicidae ) e a sua importância médica em Portugal. Desafios para o Século XXI. Acta Med Port., 24, 961-974. https://novaresearch.unl.pt/en/publications/os-mosquitos-diptera-culicidae-e-a-sua-import\%C3\%A2ncia-m\%C3\%A9dica-em-port

Catenacci, L. S., Nunes-Neto, J., Deem, S. L., Palmer, J. L., Travassos-da Rosa, E. S., \& Tello, J. S. (2018). Diversity patterns of hematophagous insects in Atlantic forest fragments and human-modified areas of southern Bahia, Brazil. Journal of Vector Ecology, 43(2), 293-304. https://doi.org/10.1111/jvec.12313

Consoli, R. A. G. B., \& Oliveira, R. L. de. (1994). Classificação e principais espécies de importância sanitária.

de Souza, A. I. S., Junior, A. L. G., de Sousa Abreu, J. L., da Silva Sampaio, J. P., de Sousa, L. G., \& Chaves, T. V. S. (2020). Casos notificados de dengue no Estado do Piauí entre os anos de 2015 a 2019. Research, Society and Development, 9(11), e59691110231-e59691110231. http://dx.doi.org/10.33448/rsdv9i11.10231

Dibo, M. R., Maria, R., Menezes, T. De, Ghirardelli, C. P., Luís, A., \& Chiaravalloti, F. (2011). Artigo / Article Presença de culicídeos em município de porte médio do Estado de São Paulo e risco de ocorrência de febre do Nilo Ocidental e outras arboviroses The presence of Culicidae species in medium-sized cities in the state of São Paulo, Brazil an. 44(4), 496-503.

Donalisio, M. R., Freitas, A. R. R., \& Von Zuben, A. P. B. (2017). Arboviroses emergentes no Brasil: desafios para a clínica e implicações para a saúde pública. 10-15. http://dx.doi.org/10.1590/s1518-8787.2017051006889

Fang, J. (2010). A world without mosquitoes. Nature, 466 (July).

Figueiredo, L. T. M. (2015). The recent arbovirus disease epidemic in Brazil. Revista Da Sociedade Brasileira de Medicina Tropical, 48(3), 233-234. https://doi.org/10.1590/0037-8682-0179-2015

Forattini, O. P., Gomes, A. C., Galati, E. A., Bianchi, Rabello, E. X., \& Natal, D. (1981). Observações sobre atividade de mosquitos culicidae, em mata residual no vale do ribeira, s. paulo, brasil *. Revista Saúde Pública, 557-586. http://dx.doi.org/10.1590/S0034-89101981000600001.

Guedes, M. L. P. (2012). Culicidae (Diptera) No Brasil : Relações Entre Diversidade, Distribuição E Enfermidades. $16(2), 283-296$.

Harbach, R. E. (2013). Culicidae Classification. Mosquito Taxonomic Inventory, http://mosquito-taxonomic-inventory.info/ simpletaxonomy/term/6045,

Lima-Camara, T. N. (2016). Arboviroses emergentes e novos desafios para a saúde pública no Brasil. Revista de Saúde Pública, 50, 36. https://doi.org/10.1590/S1518-8787.2016050006791

Lopes, N., Nozawa, C., \& Linhares, R. E. C. (2014). Características gerais e epidemiologia dos arbovírus emergentes no Brasil. Revista Pan-Amazônica de Saúde, 5(3), 10-10. https://doi.org/10.5123/S2176-62232014000300007

Medeiros-Sousa, A. R., Ceretti-Júnior, W., de Carvalho, G. C., Nardi, M. S., Araujo, A. B., Vendrami, D. P., \& Marrelli, M. T. (2015). Diversity and abundance of mosquitoes (Diptera: Culicidae) in an urban park: larval habitats and temporal variation. Acta tropica, 150, 200-209. http://dx.doi.org/10.1016/j.actatropica.2015.08.002

Natal, D. (2002). Bioecologia Do Aedes Aegypti. Biológico, 64, 205-207.

Pereira, A. N., Moraes, J., Pereira Filho, A., Brito, G., \& Rebêlo, J. M. (2017). First record of Aedeomyia squamipennis (Lynch Arribálzaga, 1878)(Diptera: Culicidae) in the state of Maranhão: epidemiological implications and distribution in Brazil. Check List, 13, 1. https://doi.org/10.15560/13.2.2084

Piauí, Fundação Cepro. (2011) Atlas do Piauí-1990, Ministério das Minas e Energia/ CPRM, Mapa Geográfico do Estado do Piauí. http://www.cepro.pi.gov.br/download/201309/CEPRO27_010bdaaa98.pdf.

Provost, M. W. (1959). The influence of moonlight on light-trap catches of mosquitoes. Annals of the Entomological Society of America, 52(3), 261271.https://doi.org/10.1093/aesa/52.3.261 
Research, Society and Development, v. 10, n. 1, e46110111814, 2021 (CC BY 4.0) | ISSN 2525-3409 | DOI: http://dx.doi.org/10.33448/rsd-v10i1.11814

Santos-Neto, L. G. D., \& Lozovei, A. L. (2008). Aspectos ecológicos de Anopheles cruzii e Culex ribeirensis (Diptera, Culicidae) da Mata Atlântica de Morretes, Paraná, Brasil. Revista Brasileira de Entomologia, 52(1), 105-111. https://doi.org/10.1590/S0085-56262008000100018

Silveira Neto, S. (1976). Manual on the ecology of insects.

Tantely, L. M., Cêtre-Sossah, C., Rakotondranaivo, T., Cardinale, E., \& Boyer, S. (2017). Population dynamics of mosquito species in a West Nile virus endemic area in Madagascar. Parasite, 24. http://dx.doi.org/ 10.1051/parasite/2017005 